\title{
PERAN KELUARGA DALAM PERILAKU PEMBELIAN HEDONIS
}

\author{
Sigit Wibawanto \\ Program Studi Manajemen \\ STIE Putra Bangsa Kebumen \\ sigitpb3@gmail.com
}

\begin{abstract}
This study aims to examine the structure of the family's role in the lifestyle of hedonism and its influence on the consumer purchasing process. Observation activities are carried out at modern markets and cafes/ restaurants in Kebumen district. This research paradigm discusses aspects of consumer behavior and marketing research regarding consumer behavior and purchasing decisions that vary and reflect the hedonic dimension. This descriptive qualitative research conducted with the purpose to understand the meaning symbolized by each family's behavior according to the family's own perspective. The results of the study show that shopping locations can cause a shift in purchasing activities in modern markets lead to hedonic behavior, but are still relatively normal. In the visit activities at cafe/ restaurant show hedonic behavior because it provides an illustration that eating outside the home as a place of discussion is considered interesting, not up to date, luxurious and worth displaying on its social media accounts. This research shows a number of the propositions that apply in the field. This research still needs to be improved, especially in the discussion of objects and research locations, including the selection of entertainment/ tourism places, as well as family strata in influencing hedonic buying behavior.
\end{abstract}

Keywords: buying behavior, hedonic lifestyle, family role, modern market, cafe/ restaurant

\section{PENDAHULUAN}

Penelitian peran keluarga dalam keputusan membeli, telah menjadi aspek penting yang perlu diketahui pemasar terutama mengenai keterlibatannya dalam pembelian. Strategi promosi melalui iklan dapat memberikan informasi yang diharapkan mampu membangkitkan kesadaran terhadap merek, untuk menangkap salah satu struktur masyarakat terkecil, yakni keluarga. Melihat pentingnya peran informasi bagi keluarga, pemasar perlu mencari informasi mengenai keterlibatan masing-masing anggota keluarga tersebut. Halhal yang perlu diketahui diantaranya jenis produk, persembahan warna dan evaluasi harga, lokasi tempat pembelian, aspek pemilihan merek. Informasi ini perlu diketahui, karena membantu pemasar untuk pengembangan penawaran produk dan strategi promosi khusus yang dilakukannya.

Literatur perilaku konsumen banyak yang menyebutnya sebagai pengambilan keputusan keluarga atau peran pembelian keluarga (Cunningham dan Green, 1974). Literatur-literatur tersebut memberikan informasi mengenai perilaku konsumen dalam keputusan pembelian, meskipun informasi tidak lengkap untuk isu-isu saat ini. Studi penelitian yang berkaitan dengan komersial akademik banyak yang menyelidiki keterlibatan anggota keluarga dan perannya yang beragam. Pembahasan ini dimulai dari tahapan dalam proses pengambilan keputusan membeli (Davis dan Rigaux, 1974; Hempel, 1974), sub keputusan pembelian untuk produk atau jasa (Davis, 1970; Hempel, 1974; Cunningham dan Green, 1974; Green and Cunningham, 1975), dan sub keputusan dan tahap keputusan untuk kategori produk dan layanan (Davis, 1970; Davis dan Rigaux, 1974; Ferber dan Lee, 1974). Faktor-faktor yang dibatasi dalam penelitian ini diantaranya luasnya peran keluarga dalam strukturnya yang tergolong dalam kategori produk yang mencerminkan gaya hidup 
hedonisme. Penelitian peneliti sebelumnya telah menyelidiki pengambilan keputusan keluarga untuk sejumlah kategori produk dan layanan, namun tidak membedakan pada gaya hidup. Davis (1976, p.248) mencatat bahwa keluarga untuk kebanyakan studi pengambilan keputusan rumah tangga kenyataannya ada pada suami dan istri, yang memiliki peran dominan. Engel, Kollat, dan Blackwell (1973, p 204.) menyampaikan banyak penelitian struktur peran terlalu meremehkan peran anak-anak, pendekatan penelitiannya komprehensif, namun belum muncul dalam literatur publik.

Tujuan penelitian ini untuk mengkaji bagaimana struktur peran keluarga dalam gaya hidup hedonisme dan pengaruhnya terhadap proses pembelian konsumen. Hasil penelitian yang dilakukan peneliti sebelumnya menemukan unsur-unsur yang diakibatkan aktivitas, minat, dan opini masyarakat akan mendapatkan suatu perilaku pembelian yang abnormal dan membuat masyarakat mengeluarkan biaya untuk mendapatkan produk yang belum tentu sesuai kebutuhan, melainkan keinginan dan emosional dalam pengambilan keputusan pembeliannya (Wibawanto, 2016). Peneliti bermaksud mengembangkan penelitian sebelumnya, sehingga peran keluarga dalam pengambilan keputusan perilaku pembelian hedonis struktur keluarga yang didominasi peran suami dan istri lebih dominan. Alasan fokus pada kedua peran ini didasarkan pada perbedaan dan kesamaan keduanya yang memiliki tahapan dan langkah-langkah terstruktur yang menjadikan peran menjadi kelihatan rumit. Penulis membatasi pada produk, tempat, atau layanan yang mencerminkan perilaku hedonis. Perilaku pembelian hedonis dapat terlihat pada saat membeli dan menghabiskan waktu diluar rumah, bepergian untuk bermain, membeli di tempat-tempat keramaian, membeli barangbarang mahal, dan kecenderungan ikut-ikutan untuk menjadi pusat perhatian (Kasali, 2003:242).

Permasalahan penelitian ini
dirumuskan secara deskriptif untuk
mengkonstruksi hubungan antara situasi satu
dengan yang lainnya secara interaktif yang

saling mempengaruhi, yaitu bagaimanakah peran keluarga dalam perilaku pembelian hedonis? Lingkup penelitian ini dibatasi pada aspek sikap hedonisme, yang mengacu pada teori Enggel, dkk (1995), peran keluarga mengacu penelitian Szybillo dan Sosanie (1977). Perilaku pembelian konsumen, lingkup penelitiannya dibatasi pada dimensi skala shopping addiction yang dikembangkan Elizabeth E. Edwards disusun berdasarkan lima dimensi yaitu tendency to spend, drive to spend, feelings about shopping, dysfunctional spending, post-purchase guilt (Moeljosoedjono, 2008). Penelitian dilakukan di wilayah kabupaten Kebumen yang merepresentasikan masyarakat saat ini yang memiliki sikap hedonisme. Penelitian ini diharapkan dapat memberikan manfaat dan pengetahuan mengenai peran keluarga (suami dan istri) yang dapat membawa perubahan pada perilaku pembelian hedonis.

\section{PERSPEKTIF TEORI DAN KAJIAN PUSTAKA}

Perspektif dalam penelitian kualitatif adalah suatu kerangka konseptual (conceptual framework), dari berbagai asumsi, nilai, atau gagasan peneliti yang dapat memberikan gambaran cara bertindak dalam situasi/ masalah yang akan diteliti. Perspektif dalam penelitian ini merupakan cara pandang peneliti dalam memberikan kebebasan kepada informan untuk memberikan data atau informasi yang akan disajikan. Tingkat kebebasan perspektif emik yang diberikan kepada responden atau informan sangat tinggi (Hamidi, 2010: 124-125). Paradigma merupakan perspektif riset yang digunakan peneliti untuk melihat realita (world views), mempelajari fenomena, cara-cara dalam penelitian dan cara-cara dalam menginterpretasikan temuan. Desain penelitian, menggambarkan pilihan suatu kepercayaan yang akan mendasari dan memberi pedoman seluruh proses penelitian (Guba, 1990). Paradigma menentukan masalah apa yang dituju dan tipe penjelasan apa yang dapat diterimanya (Kuhn, 1970). Perspektif atau paradigma penelitian yang digunakan peneliti adalah kualitatif yang memiliki tahapan berfikir kritis- 
ilmiah, dimulai dengan berfikir secara induktif untuk menangkap fakta atau fenomenafenomena sosial melalui pengamatan lapangan, menganalisis, dan melakukan teorisasi berdasarkan apa yang diamati (Bungin, 2008). Paradigma penelitian kualitatif yang peneliti gunakan adalah paradigma rasionalistik (verstehen) yang memandang realitas sosial dipahami yang didasarkan pada teori-teori dan didialogkan dengan pemahaman subjek atau data empirik. Paradigma penelitian ini membahas pada aspek perilaku konsumen dan riset pemasaran mengenai perilaku dan keputusan pembelian konsumen yang beragam dan mencerminkan dimensi hedonis.

1. Perilaku Pembelian

Perubahan perilaku mengakibatkan seseorang dapat merancang dan melaksanakan atau intervensi program yang menghasilkan perubahan perilaku yang diinginkan, dan ini dikatakan sebagai "intervensionis" (Glanz, Lewis, \& Rimmers, 1990, hal. 17). Model perubahan perilaku, diantaranya meliputi threat, fear, response efficacy, self efficacy, barriersbenefits, subjective, subjective norms, attitudes, intentions, cues to action dan reactance (Witte, K., 1997). Teori perubahan perilaku saat ini terbagi menjadi: (1) social cognitive theory, (2) theory of planned behavior, (3) transtheoretical (stages of change) model. Teori pertama, dibahas diantaranya dari Bandura (1986), yang membahas mengenai teori kognitif, banyak orang didorong bukan oleh kekuatan batin, melainkan didorong karena faktor eksternal. Modelnya menunjukkan fungsi manusia bisa dijelaskan karena adanya perilaku interaksi, pribadi dan lingkungan, yang dikenal dengan reciprocal determinism. Faktor lingkungan ini meliputi; naluri, pengendalian, sifat, dan kekuatan motivasi individu lainnya. Perry, C. L., Barnowski, T., \& Parcel, G. S. (1990) menjelaskan variabel-variabel dalam proses perubahan perilaku yaitu; self-efficacy, outcome expectations, self-control, reinforcements, emosional coping, observational learning. Teori perubahan perilaku kedua, dibahas diantaranya oleh;
Ajzen, I. (1991), Armitage, C. dan Conner, M. (2001), Grizzell, J. (2007), yang menunjukkan perilaku akan tergantung pada niat seseorang untuk melakukan perilaku, niat akan ditentukan oleh sikap individu dan norma subjektifnya. Perilaku ditentukan oleh perilaku yang dirasakan dengan kontrol moral individu. Terakhir, teori perilaku ini dibahas diantaranya oleh; Prochaska, Johnson, dan Lee (1998), yang mengusulkan tahap perubahan dalam proses, yaitu prekontemplasi, kontemplasi, persiapan, aksi, dan terminasi. Zanna dan Rempel (1988), melihat sikap dapat terjadi karena banyak penyebab. Informasi dapat mengubah sikap secara konsisten dan kongruen terhadap terhadap suatu objek. Herek (1986) menunjukkan perubahan persepsi tentang kelompok atau benda dan menciptakan situasi yang dapat menumbuhkan sikap perubahan. Kim dan Hunter (1993) menunjukkan niat bertindak sebagai mediator dalam sikap perilaku.

Perilaku konsumen, menurut James F. Engel, Roger D. Blackwell, Paul W. Miniard, dibagi menjadi tiga faktor. Pertama, adanya pengaruh lingkungan (meliputi; budaya, kelas sosial, keluarga dan situasi). Kedua yaitu karena adanya perbedaan dan pengaruh individu (meliputi; motivasi dan keterlibatan, pengetahuan, sikap, kepribadian, gaya hidup, dan demografi). Terakhir, adanya proses psikologis (meliputi; pengolahan informasi, pembelajaran, perubahan sikap dan perilaku). Boyd, Jr. dan Walker Jr. (1995) menjelaskan proses pengambilan keputusan dapat dilakukan ketika akan melakukan pembelian bervariasi dari satu konsumen ke konsumen lainnya. Assael (1998) menyebutkan bahwa proses pengambilan keputusan konsumen harus dipahami dalam pengembangan aplikasi strategik.

$\begin{array}{rlr}\text { Konsumen } & \text { dalam } & \text { perilaku } \\ \text { mbeliannya, } & \text { seringkali } & \text { tidak }\end{array}$ pembeliannya, barangnya. Konsumen cenderung akan lebih terkonsentrasi pada bagaimana mengadopsi nilai, sikap, perasaan, dan gaya hidup yang 
ditawarkan kepadanya. Perilaku belanja seperti ini tergolong dalam perilaku yang dinamakan shopping addiction. Perilaku belanja seperti ini, merupakan aktivitas berbelanja yang sifatnya abnormal (Edwards, 1993). Pelaku shopping addiction cenderung tidak akan mampu mengendalikan keinginannya atau mengontrol dirinya dalam berbelanja, dan cenderung akan melakukan upaya berulang dan terus menerus agar keinginannya dapat terpenuhi, dan tidak mampu untuk mengontrol diri (Moeljosoedjono, 2008). Kotler (2001) juga menyatakan bahwa gaya hidup merupakan pola interaksi seseorang yang diungkapkan dalam kegiatan, minat, dan pendapat seseorang.

2. Gaya Hidup Hedonisme

Modern, bergengsi, dan menyenangkan merupakan keinginan sebagian besar masyarakat. Materialisme sebagai salah satu penyebab pergeseran sikap dan budaya individuali dalam masyarakat, yang mengarah kepada kehidupan serba hedonis. Munculnya gaya hidup hedonism tersebut, akan menjadi pemicu untuk mempersepsikan seseorang sebagai human having, yaitu seseorang yang mempersepsikan orang lain berdasarkan apa yang dimilikinya. Perilaku seperti ini bersifat negative, hal ini dikarenakan hanya mementingkan kenikmatan, kesenangan dan kepuasaan duniawi. Mowen dan Minor (2002) menjelaskan gaya hidup ini telah memiliki beberapa aspek dari pernyataan AIO untuk mengetahui gaya hidup ini, yaitu: pertanyaan aktivitas (activity questions), pertanyaan minat (interest question), dan berkaitan dengan pertanyaan opini (opinion question). Lain halnya dengan pernyataan dari Well dan Tigert (Engel, 1993), yang menjelaskan ada tiga aspek gaya hidup hedonis yaitu (1) minat yang diartikan sebagai apa yang menarik, (2) aktivitas merupakan cara individu menggunakan waktunya untuk mewujudkan tindakan nyatanya, (3) opini yakni pendapat yang diberikan dalam merespon situasi. Wendy L. Billings (1990) dalam penelitiannya juga menemukan bahwa lingkungan yang dianggap sebagai sesuatu yang menyenangkan, dan bermanfaat, maka segala kegiatan yang terjadi dalam lingkungan tersebut juga akan dianggap menyenangkan dan bermanfaat.

Donovan dan Rossiter menegaskan bahwa kondisi emosional perlu variabel mediasi dengan daya prediksi yang cukup, dan ini hanya titik awal untuk menganalisis perilaku pendekatanpengindaran dalam lingkungan ritel. Perbedaan individu juga menjadi pertimbangan, karena reaksi terhadap lingkungan juga bervariasi, serta harus dibedakan antara perilaku pembelian aktual dengan niat konsumen. Francis Piron (1991), mendefinisikan pembelian impuls sebagai fenomena penting dalam perilaku konsumen terutama dalam pasar ritel. Bukti empiris ini ditemukan untuk mengukur prevalensi pembelian yang dilakukan sebagai pendorong, dan mencerminkan besarnya kegunaan pembelian impuls. Szybillo dan Sosanie (1977), menunjukkan potensi keterlibatan anak-anak dalam pengambilan keputusan keluarga yang perlu diukur struktur peran keluarga dalam pola perilaku pembelian rumah tangga. Gaya hidup hedonisme mahasiswa berasal dari pergaulan lingkungan yang tidak peka terhadap tindakan menyimpang dan kurangnya kontrol keluarga (Dauzan dan Anita, 2011).

3. Peran Keluarga

Gaya hidup keluarga maupun rumah tangga, akan mempengaruhi sebagian besar kebiasaan dalam pola dan perilaku pembelian konsumen. Tinggi derajat status dan struktur dalam keluarga akan meningkatkan tingkat perilaku konsumen dalam pilihan belanjaannya. Keluarga merupakan sebuah kelompok yang terdiri atas dua orang atau lebih yang terikat perkawinan, darah atau adopsi yang biasanya tinggal bersama dalam satu rumah. Keluarga terdiri atas dua bagian yaitu keluarga inti dan keluarga besar. Keluarga inti merupakan kelompok yang terdiri dari 
atas ayah, ibu dan anak, sedang keluarga besar terdiri dari keluarga inti ditambah keluarga lain seperti kakek, nenek, paman, bibi, sepupu dan kerabat karena perkawinan. Keluarga merupakan lingkungan yang paling dekat bagi semua anggota keluarga dan memiliki fungsi untuk mengembangkan kualitas sumber daya manusia bagi semua anggotanya, termasuk menjadikan sebagai konsumen.

Pemasar semakin tertarik dengan peran dan pengaruh relatif dari sosialisasi yang dilakukan suami, istri, dan anak-anak dalam pembelian. Sosialisasi merupakan proses yang memungkinkan bagi keluarga untuk memperoleh ketrampilan, pengetahuan, dan sikap yang berfungsi sebagai konsumen (Schiffman dan Kanuk, 2004:308). Proses sosialisasi budaya dalam keluarga dimaksudkan untuk melanjutkan makna budaya yang berlaku di dalam keluarga tersebut. Peter dan Olson, (2000:117), menyampaikan bahwa aliran sosialisasi keluarga bisa melalui orang tua dan dapat secara langsung mempengaruhi perilaku anak-anaknya, namun demikian keadaan dapat juga terjadi sebaliknya, dimana anakanak dapat mensosialisasikan kepada orang tuanya, khususnya untuk produk-produk baru. Penelitian Nelson (1979; 421) menjelaskan bahwa peran anak-anak dapat menjadi sumber informasi penting pengambilan keputusan dalam keluarga. Akan tetapi faktor pendapatan tetap menjadi faktor yang lebih berpengaruh pada perkiraan keterlibatan anak dalam pengambilan keputusan pembelian keluarga.

\section{METODE PENELITIAN}

Metodologi penelitian merupakan seperangkat pengetahuan tentang cara sistematis dan logis dalam pencarian informasi untuk mendapatkan data yang sesuai masalah penelitiannya. Melihat jenis datanya, maka pendekatan penelitian yang digunakan peneliti saat ini menggunakan pendekatan kualitatif. Penelitian kualitatif menurut Kirk dan Miller (dalam Moleong, 2010: 4), sebagai suatu tradisi dalam ilmu pengetahuan sosial diman secara fundamental bergantung pada pengamatan manusia dalam kawasannya dan akan berhubungan dengan orang-orang tersebut dalam bahasan dan peristilahannya. Pendekatan kualitatif adalah untuk memahami fenomena mengenai apa yang dialami subjek penelitian secara holistik, dan disusun dengan mendeskripsikan melalui kata-kata dan bahasa, pada suatu konteks khusus yang alamiah dan dengan memanfaatkan berbagai metode ilmiah (Moleong, 2007: 6). Penelitian kualitatif yang dilakukan saat ini, untuk memahami makna yang disimbolkan dari setiap perilaku keluarga menurut perspektif keluarga itu sendiri. Metode ini diharapkan dapat memperoleh suatu fakta yang dapat mendekati kebenaran dan dibangun atas dasar perkembangan teori-teori dan terkontrol secara empirik. .

Batasan ilmiah yang dipakai sebagai acuan dalam penelitian ini, yaitu: pada peran keluarga dalam proses pengambilan keputusan pembelian. Solomon (2007) mengatakan bahwa anggota keluarga merupakan suatu pusat pembelian organisasi yang memainkan sejumlah peran tertentu ketika membuat keputusan pembelian. Schiffman (2007) menambahkan 3 peran yang lebih merinci peran anggota keluarga berbeda dalam proses pengambilan keputusan keluarga, yaitu decider, preparer, dan disposer. Pembagian peran menurut Virmani (2013) pada dasarnya pengambilan keputusan keluarga memperlihatkan anggota keluarga yang berinteraksi, dan mempengaruhi anggota keluarga lain. Perilaku pembelian, didasarkan pada tingkat keterlibatan pembelian dan tingkat perbedaan antar mereknya. Henry Assel (1998) membedakan menjadi: (1) perilaku pembelian yang rumit, (2) pembelian pengurang ketidaknyamanan, (3) perilaku pembelian karena kebiasaan, (4) perilaku pembelian yang mencari variasi.

Hamidi (2005: 75-76) menyatakan bahwa unit analisis adalah satuan yang diteliti yang bisa berupa individu, kelompok, benda atau suatu latar peristiwa sosial seperti misalnya aktivitas individu atau kelompok sebagai subjek penelitian. Maholtra $(2007 ; 215)$, unit analisa merupakan individu, perusahaan serta pihakpihak lain yang memberikan respon terhadap 
perlakuan ataupun tindakan yang dilakukan peneliti dalam penelitiannya. Peneliti mencoba menemukan informan awal yakni orang pertama memberi informasi memadai ketika peneliti mengawali aktivitas pengumpulan data. Informan tersebut dengan menanyakan beberapa pertanyaan kepada 5 orang yang berbelanja di pasar modern dan resto konsep modern yang altivitas tersebut dilakukan bersama keluarganya. Tempat penelitian dilakukan pada keluarga yang diwawancarai pada saat berbelanja tentang untuk produk-produk yang sifatnya yang kecenderungannya lebih bersifat hedonis, yakni di restoran dan pasar modern yang ada di kabupeten Kebumen. Penelitian ini dilakukan pada bulan Januari-Februari 2018.

Berdasarkan masalah dalam penelitian yang lebih menekankan pada peran keluarga dalam menghasilkan perilaku pembelian hedonis, maka jenis penelitian ini adalah penelitian deskriptif kualitatif. Strategi penelitian dengan melakukan beberapa tahapan yaitu tahap perencanaan, tahap pelaksanaan, observasi, dan tahap refleksi peneliti. Fungsi data dalam penelitian deskriptif kualitatif adalah sebagai landasan refleksi, yang dikumpulkan oleh peneliti melalui observasi, wawancara, catatan lapangan, dan dokumentasi. Analisis data pada penelitian kualitatif ini berasal dari sumber data yang bentuk dan wujudnya berupa kumpulan pendapat yang hasilnya tidak disusun dalam struktur kategori-kategori/ klasifikasi. Kegiatan analisis data terdiri dari tiga alur kegiatan, yaitu reduksi data, penyajian data, dan terakhir penarikan kesimpulan/ verifikasi dari data yang diperoleh dan dilakukan secara bersamaan. Secara bersamaan dalam hal ini adalah bahwa kegiatan reduksi data, penyajian data, dan penarikan kesimpulan/ verifikasi merupakan suatu aktivitas yang saling menjalin sebagai proses siklus dan interaksi baik dari saat sebelum mulai pengumpulan data, selama pengumpulan data, dan sesudah pengumpulan data dalam bentuk sejajar yang membangun wawasan umum, oleh Ulber Silalahi (2009: 339), hal ini disebut sebagai analisis. Data yang valid adalah data yang tidak berbeda antar data yang dilaporkan oleh peneliti dengan data yang sesungguhnya terjadi pada obyek penelitian (Sugiyono, 2005, p. 117).

\section{HASIL PENELITIAN}

Kabupaten Kebumen, sebagai salah satu wilayah di provinsi Jawa Tengah, memiliki wilayah geografis, demografis, budaya, dan ekonomi yang bervariasi. Secara geografis, wilayah ini terdiri daratan dan perbukitan, terbagi secara administratif menjadi 26 kecamatan, sedangkan secara demografis memiliki penduduk sekitar 1,2 juta. Berkaitan dengan penelitian, berdasarkan data statistik kesejahteraan rakyat (BPS kabupaten Kebumen 2016, Katalog BPS: 4101002.3305), dengan indikator kependudukan, kesehatan, pendidikan, perumahan, kabupaten tergolong wilayah yang masih perlu pengembangan program-program peningkatan kesejahteraan masyarakatnya. Selain itu, tingkat konsumsi dan pengeluaran rumah tangga masyarakat antara kepentingan makanan dan non makanan hampir berimbang, $54,37 \%$ untuk makanan dan non makanan 45,63\% (BPS kabupaten Kebumen 2017, Katalog BPS: 4101002.3305).

Pertumbuhan pasar modern yang mulai tersebar sampai ke pelosok ibu kota kecamatan, dan tumbuhnya konsep resto baru dengan berbagai menu pada akhirnya menarik perilaku dan mendorong masyarakat untuk mencobanya. Perilaku ini tidak lepas dengan naiknya pendapatan dan modernisasi yang dipengaruhi media dalam memberikan informasi dan tawaran menarik bagi individu maupun kelompok. Penelitian ini dilakukan agar penulis mampu memahami perubahan perilaku yang menyebabkan aktivitas belanja yang lebih memilih pasar modern dan memilih tempat bersantai bersama keluarga di resto modern. Penelitian dilaksanakan dengan menemukan sebanyak 5 informan dan dilanjutkan jika masih terbukanya peluang informasi yang bisa digali berkaitan dengan permasalahan penelitian. Data penelitian diperoleh dari data observasi berupa pengamatan dan interview.

1. Pemilihan Berbelanja Di Pasar Modern

Kegiatan pengamatan di lapangan ini, dilakukan dengan mendatangi tempat pasar modern, ada dua tempat yang penulis 
anggap bisa menjadi keterwakilan mengenai permasalahan penelitian, yaitu Toserba Jadi Baru dan Rita Pasaraya. Kegiatan ini dilakukan pada bulan Januari-Februari 2018. Kegiatan yang dilakukan adalah dengan menanyakan alasan berbelanjanya; mengenai apa motif berbelanja, bagaimana memilih dan melakukan aktivitas berbelanja di lokasi tersebut, mengapa harus belanja di tempat tersebut. Kegiatan awal yang dilakukan dengan cara membuat perencanaan terhadap pemilihan informan yang sesuai. Berikutnya adalah meminta kesediaan untuk menanyakan mengenai tempat tinggal informan, intensitas kunjungan, bersama siapa dan alasannya, daya tarik lokasi tersebut, tujuan belanjanya, dan yang terakhir adalah evaluasinya yaitu dampak apa bagi keluarga (anak-anak) setelah melakukan belanja di lokasi tersebut. Berdasarkan pertanyaan tersebut dapat ditemukan hasil yang ditunjukkan dalam tabel berikut:

Tabel 1

Karateristik Informan Berdasarkan Kriteria Intensitas Kunjungan

\begin{tabular}{clll}
\hline \multirow{2}{*}{ Informan } & \multicolumn{1}{c}{ Domisili } & \multicolumn{2}{c}{ Lokasi } \\
\cline { 3 - 4 } & & Rita Pasaraya & Jadi Baru \\
\hline 1 & Kebumen & Ridak Terlalu Sering & \\
\hline 2 & Kebumen & Insidental & \\
\hline 3 & Kebumen & Sering & \\
\hline 4 & Kebumen & Berkali-kali & Insidental \\
\hline 5 & Kebumen & & Insidental \\
\hline 6 & Alian & Insidental & Rutin \\
\hline 7 & Kutowinangun & & Berkali-kali \\
\hline 8 & Pejagoan & & Berkali-kali \\
\hline 9 & Pejagoan & & Sering \\
\hline 10 & Sruweng & & Insidental \\
\hline 11 & Buluspesantren & & Insidental \\
\hline 12 & Klirong & & \\
\hline 13 & Buluspesantren & & \\
\hline 14 & Padureso & & \\
\hline
\end{tabular}

Tabel 2

Karateristik Informan Berdasarkan Kriteria Alasan Kunjungan

\begin{tabular}{|c|c|c|c|}
\hline \multirow{2}{*}{ Informan } & \multirow{2}{*}{ Domisili } & \multicolumn{2}{|c|}{ Lokasi } \\
\hline & & Rita Pasaraya & Jadi Baru \\
\hline 1 & Kebumen & Belanja dan jalan-jalan & \\
\hline 2 & Kebumen & Belanja dan jalan-jalan & \\
\hline 3 & Kebumen & Ada kebutuhan & \\
\hline 4 & Kebumen & Belanja dan jalan-jalan & \\
\hline 5 & Kebumen & Belanja dan jalan-jalan & \\
\hline 6 & Alian & & $\begin{array}{l}\text { Belanja dan jalan- } \\
\text { jalan }\end{array}$ \\
\hline 7 & Kutowinangun & & $\begin{array}{l}\text { Belanja dan jalan- } \\
\text { jalan }\end{array}$ \\
\hline 8 & Pejagoan & Ada kebutuhan & \\
\hline 9 & Pejagoan & & Ada kebutuhan \\
\hline 10 & Sruweng & & Belanja dan jalan- \\
\hline
\end{tabular}




\begin{tabular}{|c|c|c|}
\hline & & jalan \\
\hline 11 & Buluspesantren & $\begin{array}{l}\text { Belanja dan jalan- } \\
\text { jalan }\end{array}$ \\
\hline 12 & Klirong & $\begin{array}{l}\text { Belanja dan jalan- } \\
\text { jalan }\end{array}$ \\
\hline 13 & Buluspesantren & $\begin{array}{l}\text { Belanja dan jalan- } \\
\text { jalan }\end{array}$ \\
\hline 14 & Padureso & Ada kebutuhan \\
\hline
\end{tabular}

Tabel 3

Karateristik Informan Berdasarkan Kriteria Daya Tarik

\begin{tabular}{|c|c|c|c|}
\hline \multirow{2}{*}{ Informan } & \multirow{2}{*}{ Domisili } & \multicolumn{2}{|c|}{ Lokasi } \\
\hline & & Rita Pasaraya & Jadi Baru \\
\hline 1 & Kebumen & $\begin{array}{lll}\text { Kualitas } & \text { Produk } & \text { Yang } \\
\text { Dijual } & & \end{array}$ & \\
\hline 2 & Kebumen & $\begin{array}{l}\text { Produk Yang Dijual Lebih } \\
\text { Bermerek }\end{array}$ & \\
\hline 3 & Kebumen & Lengkap & \\
\hline 4 & Kebumen & Lengkap & \\
\hline 5 & Kebumen & $\begin{array}{ll}\text { Kualitas } & \text { Produk } \\
\text { Dijual } & \\
\end{array}$ & \\
\hline 6 & Alian & & Harga Terjangkau \\
\hline 7 & Kutowinangun & & Ada Foodcourt \\
\hline 8 & Pejagoan & Lengkap & \\
\hline 9 & Pejagoan & & Harga Terjangkau \\
\hline 10 & Sruweng & & Ada Foodcourt \\
\hline 11 & Buluspesantren & & Parkir luas \\
\hline 12 & Klirong & & Ada Foodcourt \\
\hline 13 & Buluspesantren & & Parkir luas \\
\hline 14 & Padureso & & Harga Terjangkau \\
\hline
\end{tabular}

Tabel 4

Karateristik Informan Berdasarkan Kriteria Tujuan Belanja

\begin{tabular}{|c|c|c|c|}
\hline \multirow{2}{*}{$\begin{array}{l}\text { Inform } \\
\text { an }\end{array}$} & \multirow{2}{*}{ Domisili } & \multicolumn{2}{|c|}{ Lokasi } \\
\hline & & Rita Pasaraya & Jadi Baru \\
\hline 1 & Kebumen & Kebutuhan rumah tangga & \\
\hline 2 & Kebumen & $\begin{array}{l}\text { Melengkapi barang rumah } \\
\text { tangga }\end{array}$ & \\
\hline 3 & Kebumen & Kebutuhan rumah tangga & \\
\hline 4 & Kebumen & $\begin{array}{l}\text { Melengkapi barang rumah } \\
\text { tangga }\end{array}$ & \\
\hline 5 & Kebumen & $\begin{array}{l}\text { Melengkapi barang rumah } \\
\text { tangga }\end{array}$ & \\
\hline 6 & Alian & & $\begin{array}{l}\text { Kebutuhan } \\
\text { tangga }\end{array}$ \\
\hline 7 & $\begin{array}{l}\text { Kutowinang } \\
\text { un }\end{array}$ & & $\begin{array}{l}\text { Menyenangkan } \\
\text { keluarga }\end{array}$ \\
\hline
\end{tabular}




\begin{tabular}{|c|c|c|c|}
\hline 8 & Menyenangkan keluarga & & \\
\hline 9 & Pejagoan & $\begin{array}{l}\text { Kebutuhan } \\
\text { tangga }\end{array}$ & rumah \\
\hline 10 & Sruweng & $\begin{array}{l}\text { Menyenangkan } \\
\text { keluarga }\end{array}$ & \\
\hline 11 & $\begin{array}{l}\text { Buluspesantr } \\
\text { en }\end{array}$ & $\begin{array}{l}\text { Melengkapi } \\
\text { rumah tangga }\end{array}$ & barang \\
\hline 12 & Klirong & $\begin{array}{l}\text { Menyenangkan } \\
\text { keluarga }\end{array}$ & \\
\hline 13 & $\begin{array}{l}\text { Buluspesantr } \\
\text { en }\end{array}$ & $\begin{array}{l}\text { Menyenangkan } \\
\text { keluarga }\end{array}$ & \\
\hline 14 & Padureso & $\begin{array}{l}\text { Kebutuhan } \\
\text { tangga }\end{array}$ & rumah \\
\hline
\end{tabular}

Tabel 5

Karateristik Informan Berdasarkan Kriteria Dampak Belanja Bagi Keluarga

\begin{tabular}{|c|c|c|c|}
\hline \multirow{2}{*}{$\begin{array}{c}\text { Informa } \\
\text { n }\end{array}$} & \multirow{2}{*}{ Domisili } & \multicolumn{2}{|c|}{ Lokasi } \\
\hline & & Rita Pasaraya & Jadi Baru \\
\hline 1 & Kebumen & Tidak berdampak apa-apa & \\
\hline 2 & Kebumen & $\begin{array}{l}\text { Belanja selalu di toko/ pasar } \\
\text { modern }\end{array}$ & \\
\hline 3 & Kebumen & $\begin{array}{l}\text { Belanja selalu di toko/ pasar } \\
\text { modern }\end{array}$ & \\
\hline 4 & Kebumen & $\begin{array}{l}\text { Belanja selalu di toko/ pasar } \\
\text { modern }\end{array}$ & \\
\hline 5 & Kebumen & Tidak berdampak apa-apa & \\
\hline 6 & Alian & & $\begin{array}{l}\text { Tidak berdampak apa- } \\
\text { apa }\end{array}$ \\
\hline 7 & $\begin{array}{l}\text { Kutowinang } \\
\text { un }\end{array}$ & & Sekali-kali \\
\hline 8 & Pejagoan & $\begin{array}{l}\text { Belanja selalu di toko/ pasar } \\
\text { modern }\end{array}$ & \\
\hline 9 & Pejagoan & & $\begin{array}{l}\text { Tidak berdampak apa- } \\
\text { apa }\end{array}$ \\
\hline 10 & Sruweng & & $\begin{array}{l}\text { Belanja selalu di toko/ } \\
\text { pasar modern }\end{array}$ \\
\hline 11 & $\begin{array}{l}\text { Buluspesant } \\
\text { ren }\end{array}$ & & Sekali-kali \\
\hline 12 & Klirong & & $\begin{array}{l}\text { Belanja selalu di toko/ } \\
\text { pasar modern }\end{array}$ \\
\hline 13 & $\begin{array}{l}\text { Buluspesant } \\
\text { ren }\end{array}$ & & $\begin{array}{l}\text { Tidak berdampak apa- } \\
\text { apa }\end{array}$ \\
\hline 14 & Padureso & & Sekali-kali \\
\hline
\end{tabular}

2. Pemilihan Tempat Kumpul Keluarga Di Kafe menunjukkan gejala hedonis dalam dan Restoran Fast Food

Kegiatan pengamatan berikutnya adalah pengamatan pada kafe dan resto yang peneilitian ini adalah kafe dan restoran siap saji (fast food), yaitu kafe Royal Cafe dan restoran fast food Rocket Chicken. Kedua 
tempat ini dipilih dengan alasan bahwa tempat ini disukai karena memberikan gambaran bahwa makan di luar rumah dan tempat diskusi bisa menarik berjalan disini. Kedua tempat ini juga memberikan kesan tidak ketinggalan jaman dan mewah yang layak dipamerkan di akun media sosialnya.
Kegiatan wawancara yang dilakukan dengan memberi pertanyaan mengenai aspek apa yang membuatnya menarik untuk mengunjungi tempat tersebut, alasan kunjungan, serta siapa yang menentukan melakukan kunjungan.

Tabel 6

Karateristik Informan Berdasarkan Kriteria Aspek Yang Menarik

\begin{tabular}{|c|c|c|c|}
\hline \multirow{2}{*}{$\begin{array}{c}\text { Informa } \\
n\end{array}$} & \multirow{2}{*}{ Domisili } & \multicolumn{2}{|c|}{ Lokasi } \\
\hline & & Royal Cafe & Rocket Chicken \\
\hline 1 & Kebumen & Tampak menarik dari luar & Tampak menarik dari luar \\
\hline 2 & Kebumen & Akses mudah & Akses mudah \\
\hline 3 & Alian & $\begin{array}{l}\text { Interior tampak menarik } \\
\text { dari luar }\end{array}$ & $\begin{array}{l}\text { Interior tampak menarik dari } \\
\text { luar }\end{array}$ \\
\hline 4 & $\begin{array}{l}\text { Kutowinang } \\
\text { un }\end{array}$ & $\begin{array}{l}\text { Informasi tawaran tampak } \\
\text { menarik dari luar }\end{array}$ & $\begin{array}{l}\text { Informasi tawaran tampak } \\
\text { dari luar }\end{array}$ \\
\hline 5 & Pejagoan & Akses mudah & $\begin{array}{l}\text { Interior tampak menarik dari } \\
\text { luar }\end{array}$ \\
\hline 6 & Pejagoan & Akses mudah & Akses mudah \\
\hline 7 & Sruweng & $\begin{array}{l}\text { Informasi tawaran tampak } \\
\text { dari luar }\end{array}$ & Akses mudah \\
\hline 8 & Klirong & $\begin{array}{l}\text { Informasi tawaran tampak } \\
\text { dari luar }\end{array}$ & $\begin{array}{l}\text { Informasi tawaran tampak } \\
\text { dari luar }\end{array}$ \\
\hline 9 & $\begin{array}{l}\text { Buluspesant } \\
\text { ren }\end{array}$ & $\begin{array}{l}\text { Informasi tawaran tampak } \\
\text { dari luar }\end{array}$ & $\begin{array}{l}\text { Informasi tawaran tampak } \\
\text { dari luar }\end{array}$ \\
\hline 10 & Ambal & $\begin{array}{l}\text { Informasi tawaran tampak } \\
\text { dari luar }\end{array}$ & Tampak menarik dari luar \\
\hline
\end{tabular}

Tabel 7

Karateristik Informan Berdasarkan Kriteria Alasan Kunjungan

\begin{tabular}{|c|c|c|c|}
\hline \multirow{2}{*}{ Informan } & \multirow{2}{*}{ Domisili } & \multicolumn{2}{|c|}{ Lokasi } \\
\hline & & $\begin{array}{l}\text { Royal Cafe } \\
\end{array}$ & Rocket Chicken \\
\hline 1 & Kebumen & Sekedar berakhir pekan & Tidak masak di rumah \\
\hline 2 & Kebumen & Baru menerima gaji & Tidak masak di rumah \\
\hline 3 & Alian & Menyenangkan keluarga & Menyenangkan keluarga \\
\hline 4 & Kutowinangun & Liburan & Menyenangkan keluarga \\
\hline 5 & Pejagoan & Menyenangkan keluarga & Sekedar berakhir pekan \\
\hline 6 & Pejagoan & Baru menerima gaji & Menyenangkan keluarga \\
\hline 7 & Sruweng & Menyenangkan keluarga & Baru menerima gaji \\
\hline 8 & Klirong & Sekedar berakhir pekan & Menyenangkan keluarga \\
\hline 9 & Buluspesantren & Baru menerima gaji & Baru menerima gaji \\
\hline 10 & Ambal & Baru menerima gaji & Liburan \\
\hline
\end{tabular}


Tabel 8

Karateristik Informan Berdasarkan Kriteria Yang Menentukan Kunjungan

\begin{tabular}{|c|c|c|c|}
\hline \multirow{2}{*}{ Informan } & \multirow{2}{*}{ Domisili } & \multicolumn{2}{|c|}{ Lokasi } \\
\hline & & Royal Cafe & Rocket Chicken \\
\hline 1 & Kebumen & Suami & Istri \\
\hline 2 & Kebumen & Anak & Anak \\
\hline 3 & Alian & Suami & Anak \\
\hline 4 & Kutowinangun & Suami & Istri \& Anak \\
\hline 5 & Pejagoan & Istri & Anak \\
\hline 6 & Pejagoan & Suami \& Anak & Istri \\
\hline 7 & Sruweng & Suami & Suami \\
\hline 8 & Klirong & Suami & Istri \& Anak \\
\hline 9 & Buluspesantren & Suami & Istri \& Anak \\
\hline 10 & Ambal & Istri & Istri \\
\hline
\end{tabular}

\section{PEMBAHASAN TEMUAN PENELITIAN}

Berdasarkan temuan hasil penelitian, selanjutnya dilakukan pembahasan sesuai dengan teori dan logika. Pembahasan ini akan disajikan sesuai dengan permasalahan yang diteliti.

1. Pemilihan Berbelanja Di Pasar Modern

Lokasi berbelanja untuk era masyarakat yang serba digital dan modern menyebabkan pergeseran belanja dari pasar model tradisional ke pasar modern. Namun belum nampak pada perubahan perilaku konsumen yang dianggap normal, mengingat dalam kesehariannya pola konsumsi masyarakat masih melibatkan pasar tradisional untuk memenuhi kebutuhannya. Dapat dikatakan bahwa masyarakat belum sepenuhnya berubah pola perilaku berbelanjanya ke pasar modern. Hal ini dikarenakan fasilitasnya belum lengkap seperti yang ada di kota-kota besar di Indonesia. Daya beli masyarakat Kebumen masih dipengaruhi beberapa faktor, diantaranya sisi sosial, budaya, dan religiusitas yang masih melekat pada. Hal ini sesuai pendapat Schiffman dan Kanuk (2008:6), bahwa perilaku konsumen digambarkan sebagai cara individu dalam mengambil keputusan untuk memanfaatkan sumber daya mereka yang tersedia (waktu, uang, dan usaha) guna membeli barangbarang yang berhubungan dengan konsumsi. Melihat paradigma, dapat dikatakan bahwa perilaku belanja masyarakat Kebumen, cenderung bukan pada perubahan paradigma masyarakat menuju ke arah modern. Mengingat tujuan pemilihan pasar modern belum sepenuhnya tergantung pada pasar modern, dan sekedar kesenangan diri dan orang lain serta sifatnya sesaat dan tidak rutin.

2. Pemilihan Tempat Kumpul Keluarga Di Kafe dan Restoran Fast Food

Setiap individu membutuhkan seseorang atau sekumpulan orang, tempat, ataupun suasana sebagai upaya untuk menghilangkan rasa jenuh, suntuk, dan malas melalui pengalihan maupun penyaluran emosi yang menghinggapinya. Seseorang atau sekelompok orang ini dibutuhkan orang lainnya sebagai tempat dirinya berkeluh kesah, menceritakan sesuatu yang diamati dan pengalaman orang lain untuk didengarkan. Peran dalam penelitian ini adalah peran keluarga, dimana keluarga mampu menjadi tempat yang paling banyak diminati untuk bertemu, berdiskusi, ataupun tempat berkeluh kesah dengan segala konsekuensinya. Keluarga menjadi faktor yang penting dalam mempengaruhi perilaku seseorang untuk merubah dan menuntun sesuai dengan kepentingan keluarga. Termasuk dalam pemenuhan kebutuhan, wisata, ataupun pemilihan tempat berdiskusi, hal ini keluarga sangat memiliki 
peran terhadap perilaku pembelian, bahkan sampai pada perilaku hedonis yang sesuai dengan pembahasan penelitian saat ini. Berdasarkan aspek yang menarik konsumen untuk mendatangi tempat tersebut, disebabkan karena tempat tersebut tampak menarik dari luar berdasarkan design papan reklame, penerangan, dan warna yang menarik, akses mudah, dan interior tampak menarik dari luar. Berdasarkan kriteria alasan kunjungan konsumen, rata-rata kunjungan konsumen didasarkan pada alasan yang mengungkapkan hanya sekedar berakhir pekan, tidak masak di rumah, menyenangkan keluarga, liburan, baru terima gaji. Hal ini menunjukkan bahwa aktivitas konsumen untuk melakukan kunjungan, merupakan perilaku-perilaku hedonis yang cenderung lebih menyukai aktivitas senang-senang dan memilih untuk tidak lebih menyukai masakan di rumah. Pada aspek siapa yang menentukan kunjungan tersebut, diketahui bahwa kunjungan keluarga dipengaruhi oleh suami, istri, anak, ataupun kombinasi diantara mereka. Temuan menunjukkan bahwa yang terbanyak dalam penentuan kunjungan tersebut hampir berimbang diantara suami, istri maupun kombinasinya. Namun, kombinasi pengambilan keputusan kunjungan terbanyak dilakukan antara istri dan anak. Hal ini mengingat tempat penelitian ini, rata-rata keluarga yang dibawa sebagian besar masih tergolong anak-anak. Meskipun tetap banyak yang remaja, namun posisi anak yang lebih muda secara usia lebih dominan dalam penentuan kunjungan dan istri menyetujuinya.

\section{KESIMPULAN DAN REKOMENDASI}

Kegiatan pengamatan pada pasar modern, dilakukan dengan menanyakan alasan berbelanja, tempat tinggal, intensitas kunjungan, bersama siapa dan alasannya, daya tarik lokasi, tujuan belanjanya, dan dampak apa bagi keluarga setelah melakukan belanja di lokasi tersebut. Hasil penelitian menunjukkan bahwa lokasi berbelanja dapat menyebabkan pergeseran pola perilaku pembelian pada pasar modern yang mengarah kepada perilaku hedonis. Akan tetapi perubahan perilaku tersebut masih tergolong normal, hal ini karena masih melibatkan pasar tradisional dalam pemenuhan kebutuhannya. Fasilitas yang belum lengkap, daya beli masyarakat menjadi faktor yang membuat ketergantungan pada pasar modern. Paradigma ini, menunjukkan perilaku belanja masyarakat Kebumen bukan pada perubahan paradigma masyarakat modern dan hanya sekedar kesenangan dan sifatnya tidak rutin, yang membawa ke arah perilaku hedonis meskipun efeknya tidak dirasakan secara langsung. Pada pengamatan aktivitas kunjungan pada kafe dan resto menunjukkan perilaku hedonis, karena memberikan gambaran bahwa makan di luar rumah, sebagai tempat diskusi dianggap menarik. Disamping itu kafe dan resto dapat memberikan kesan bahwa kedua tempat tidak ketinggalan jaman dan mewah serta layak dipamerkan di akun media sosialnya.

Penelitian ini menunjukkan sedikit banyak proposisi yang berlaku di lapangan. Pengaruh lokasi berbelanja dapat menyebabkan pergeseran pasar model tradisional ke perilaku pembelian pasar modern. Meskipun belum begitu nampak perubahan perilaku tersebut, namun dapat dianggap dapat berpengaruh terhadap perilaku hedonisme masyarakat. Peran keluarga, sebagai tempat bertemu, berdiskusi, tempat berkeluh kesah dengan segala konsekuensinya termasuk memilih tempat kafe/resto untuk melakukannya, menjadi faktor penting yang mempengaruhi perilaku sesuai kepentingan keluarga.

Penelitian ini hanya membahas mengenai aspek dan peran keluarga dalam mempengaruhi perilaku pembelian hedonis. Penelitian ini masih banyak memiliki kekurangan diantaranya peneliti tidak mencari kebutuhan lain yang mempengaruhi perilaku pembelian hedonis, hanya pada pasar modern dan kafe/ resto. Bagi penelitian selanjutnya, penulis memberikan saran obyek dan lokasi penelitian mengenai faktor-faktor keluarga yang cenderung dapat mempengaruhi perilaku hedonis, diantaranya pemilihan tempat hiburan/ wisata, yang berbeda karakteristiknya. Selain itu, penulis juga memberikan saran tentang penelitian 
selanjutnya yaitu mengenai strata dalam keluarga dalam mempengaruhi perilaku pembelian yang hedonis.

\section{DAFTAR PUSTAKA}

Ajzen, I. 1991. The Theory of Planned Behavior. Organizational Behavior and Human Decision Processes, 50, 179211.

Armitage, C., \& Conner, M. (2001). Efficacy of the theory of planned behaviour: A meta-analytic review. British Journal of Social Psychology, 40, 471-499.

Assael, Henry, 1998, Consumer Behavior and Marketing Action. $6^{\text {th }}$ edition. Cengage Learning.

Bandura, A. 1986. Social Foundations of Thought and Action. Englewood Cliffs, New Jersey: Prentice-Hall.

Bungin, Burhan., 2008, Metodologi Penelitian Kualitatif. Edisi Pertama. Kencana Prenada Media Group. Jakarta

Dedy Mulyana, 2013, Metodologi Penelitian Kualitatif, Bandung: PT Remaja Rosdakarya. h. 16

D.,P., Dauzan, dan D. Anita., 2011, Potret Gaya Hidup Hedonisme Di Kalangan Mahasiswa (Studi pada Mahasiswa Sosiologi FISIP Universitas Lampung), Jurnal Sociologie, Vol. 1, No. 3: 184193.

D. J. Hempel, "Family Buying Decisions: A Cross Cultural Perspective," Journal of Marketing Research, 11 (August 1974), 295-302.

Edwards, A. Elizabeth, 1993, Develompent of A New Scale for Measuring Compulsive Buying Behavior, Financial Counseling and Planning, 4. Michigan: Michigan University Dept

Francis Piron (1991), "Defining Impulse Purchasing", in NA - Advances in Consumer Consumer Research Volume 18, eds. Rebecca H. Holman and
Michael R. Solomon, Provo, UT: Asosiasi Consumer Research, Page: 509-514.

George J. Szybillo and Arlene Sosanie, 1977, "Family Decision Making: Husband, Wife and Children", in NA - Advances in Consumer Research Volume 04, eds. William D. Perreault, Jr., Atlanta, GA: Association for Consumer Research, Pages: 46-49.

Glanz, K., Lewis, F. M., \& Rimers, B. K. (Eds.), 1990, Health Behavior and Health Education: Theory, Research, and Practice. San Francisco, CA: JosseyBass.

Guba, Egon, Ed.,1990, The Paradigm Dialog, Newbury Park, London, New Delhi: SAGE Publications.

Grizzell, J. (2007, 1/27/2007). Behavior Change Theories and Models. Retrieved January 28, 2007.

H. Davis and B.P. Rigaux. "Perception of Marital Roles in Decision Processes," Journal of Consumer Research, 1 (June 1974), 51-62.

H. L. Davis, "Dimensions of Marital Roles in Consumer Decision Making," Journal of Marketing Research, 7 (May 1970), 168-177.

H. L. Davis, "Decision Making Within the Household," Journal of Consumer Research, 2 (March 1976), 241-260.

Hamidi. 2004. Metode Penelitian Kualitatif: Aplikasi Praktis Pembuatan Proposal dan Laporan Penelitian. Malang: UMM Press. Hal 14-16

Herek, G. (1986). The instrumentality of attitudes: Toward a neofunctional theory. Journal of Social Issues, 42:2, 99-114.

I.C.M. Cunningham and R.T. Green. "Purchasing Roles in the U.S. Family, 1955 arid 1973," Journal of Marketing, 38 (October 1974), 61-64. 
J. F. Engel, D.T. Kollat and R.D. Blackwell. Consumer Behavior. 2nd ed. New York: Holt, Rinehart and Winston, Inc., 1973.

Kasali, Rhenald, 2003, Membidik Pasar Indonesia: Segmentasi, Targeting, dan Positioning. Cetakan kelima. Jakarta: PT Gramedia Pustaka Utama.

Kotler, Philip, 2001, Manajemen Pemasaran: Analisis, Perencanaan, Implementasi, dan Kontrol. Jakarta : PT. Prehallindo

Kuhn, Thomas, 1970, The Structure of Scientific Revolution ( $2^{\text {nd }}$ edn), Chicago: The University of Chicago Press

Kim, M. S., \& Hunter, J. E. (1993). Relationships among attitudes, behavioral intentions, and behavior: A meta-analysis of past research, part 2 . Communication Research, 20:3, 331364.

Lexi J. Moleong, Metodologi Penelitian Kualitatif (Bandung: Remaja Rosdakarya, 2008), hal. 86

Moeljosoedjono, H. K. (2008). Attachment Style Pada Wanita yang Mengalami Shopping Addiction. Skripsi. Universitas Indonesia.

Olson, Jerry and Paul Peter. 2008. Consumer Behavior \& Marketing Strategy, 7th edition. New York: McGraw Hill.

Prochaska, J.O., Johnson, S.S., \& Lee, P.,1998, The Transtheoretical Model of behavior change. In E.Schron, J. Ockene, S. Schumaker, \& Exum, W.M. (Eds.), The handbook of behavioral change, second edition, New York: Springer.

Perry, C. L., Barnowski, T., \& Parcel, G. S. 1990. How individuals, environments, and health behavior interact: Social learning theory. In K. Glanz, F. M. Lewis \& B. K. Rimer (Eds.), Health Behavior and Health Educaiton:
Theory Research and Practice. San Francisco, CA: Jossey-Bass.

R. Ferber and L.C. Lee. "Husband and Wife Influence in Family Purchasing Behavior," Journal of Consumer Research, 1 (June 1974), 43-50.

R. T. Green and I.C.M. Cunningham. "Feminine Role Perception and Family Purchasing Decisions," Journal of Marketing Research, 12 (August 1975), 325-332.

Schiffman dan Kanuk, 2004, Perilaku Konsumen, Edisi 7, Prentice Hall. Jakarta.

Setiadi, N. 2008. Perilaku Konsumen Konsep dan Implikasi untuk Strategi dan Penelitian Pemasaran. Kencana. Jakarta.

Solomon R. Michael. 2007. 7th Consumer Behavior: Buying, Having, and being. Pearson International Edition.

Sugiyono, 2012, Memahami Penelitian Kualitatif, Bandung: Alfabeta.

Virmani M. 2013. Journal of Sociological Research: Modeling Buying Pattern in Emerging Indian Urban Families. Vol.4. No.1. pp.378-389

Wibawanto, Sigit., 2016, Gaya Hidup Hedonisme Terhadap Perilaku Pembelian Di Pasar Modern, Jurnal Fokus Bisnis, Vol 14. No 1.

Witte, K. 1997. Research review theory-based interventions and evaluations of outreach efforts [electronic version]. Planning and Evaluating Information Outreach among Minority Communities: Model Development Based on Native Americans in the Pacific Northwest.

Zanna, M. P., \& Rempel, J. K. 1988. Attitudes: A new look at an old concept. In D. Bartal \& A. W. Kruglanski (Eds.), The social psychology of knowledge, 315334. Cambridge, UK: Cambridge University Press. 